DOI: 10.4274/turkderm.47.s6

\title{
Mast hücreleri ve aktivasyonu
}

\author{
Mast cells and their activations
}

Dilek Bayramgürler, Evren Odyakmaz Demirsoy

Kocaeli Üniversitesi Tıp Fakültesi, Dermatoloji Anabilim Dalı, Kocaeli, Türkiye

\section{Özet}

Geleneksel olarak IgE bağımlı ani hipersensitivite reaksiyonlarının major hücreleri olarak bilinen mast hücrelerinin günümüzde hem doğal hem de edinsel bağışıkık yanıtlarının birçok basamağında efektör hücreler olarak görev aldıkları dikkati çekmiştir. Mast hücreleri, çeşitli uyaranlara yanıt olarak, depolarında hazır bulunan ya da yeni üretilen ve proinflamatuar, antiinflamatuar ve/veya immunsupresif fonksiyonlar gösterebilen biyolojik olarak aktif birçok medyatör salgılarlar. Bu makalede mast hücreleri ve aktivasyonları, mast hücre medyatörleri, inflamasyon ve bağışıklık sistemi üzerindeki rolleri ile ilgili güncel bilgiler ele alınacaktır. (Türkderm 2013; 47: Özel Sayı 1: 37-40)

Anahtar Kelime: Mast hücreleri, mast hücre activasyonu

\section{Summary}

Mast cells which are traditionally known as the major cells of IgE-dependent immediate hypersensitivity reactions are currently recognized to have a role as effector cells in many settings of the both innate and adaptive immunity. Mast cells secrete a wide spectrum of preformed or newly synthesized biologically active mediators with proinflammatory, anti-inflammatory and/or immunosupressive functions, in response to several stimuli. Current knowledge about mast cells and their activation, mast cell mediators, their roles in inflammation and immune system will be discussed in this review.

(Turkderm 2013; 47: Suppl 1: 37-40)

Key Words: Mast cells, mast cell activation

\section{Giriş}

Illk olarak 1878 yılında Paul Erlich tarafından tanımlanmış olan ve geleneksel olarak ani hipersensitivite reaksiyonlarında major rol oynayıp 'alerji hücreleri' olarak bilinen mast hücrelerinin günümüzde bağışıklık sisteminin önemli bir parçası olduğu kabul edilmektedir1,2. Mast hücrelerini bağışıklık sisteminin diğer hücrelerinden ayıran ve ilk tanımlandıkları andan itibaren bilinen en önemli özellikleri sitoplazmalarında çok sayıda granül bulundurmalarıdır. Bu granüller Taluidin mavisi, Alcien mavisi, Azure A gibi boyalarla metakromatik olarak boyanırlar. Son yıllarda ise mast hücrelerinin membranlarında bağışıklık sisteminin farklı hücreleriyle ilişki ve etkileşime girmelerini sağlayan çok sayıda reseptör bulundurdukları gösterilmiştir ${ }^{3}$. Mast hücreleri kemik iliği kökenli hücreler olup dolaşımda progenitör hücreler olarak bulunurlar; olgunlaşma ve farklılaşmaları ise dokuda gerçekleşir. Mast hücrelerinin büyüme, farklılaşma ve yaşamlarının devamı için üzerlerindeki c-kit reseptörlerinin [SCF(kök hücre faktörü) reseptörü] aktivasyonu gereklidir. Bu reseptörü aktive eden en önemli faktör başlıca endotel hücreleri, fibroblastlar ve stromal hücreler üzerinde sunulan SCF'dir. SCF dışına T hücre kökenli interlökin (IL) -3, IL-4, IL-6, IL-9 mast hücre aktivasyonuna yol açan diğer önemli sitokinlerdir1,3-6. c-kit aktivasyonunun öneminin anlaşılmasından sonra sistemik mastositoz tedavisinde imatinib mesilat gibi c-kit reseptör inhibitörlerinin kullanımı ile başarıı sonuçlar alındığı bildirilmiştir?.

Hemen hemen tüm vaskülerize dokularda bulunan mast hücreleri deri, gastrointestinal kanal ve solunum yolları gibi vücudun dış ortamlara açıldığı alanlarda daha yoğun olarak

Yazışma Adresi/Address for Correspondence: Dr. Dilek Bayramgürler, Kocaeli Üniversitesi Tıp Fakültesi, Dermatoloji Anabilim Dalı, Kocaeli, Türkiye Tel.: +902623037404 E-posta: dbayramgurler@kocaeli.edu.tr 
bulunup bu alanlarda gözcü rol oynayan ve dokulardaki yarı ömürleri aylarla ölçülen uzun ömürlü hücrelerdir 3,5 .

Mast hücreleri, farklı dokularda farklı medyatör profillerine ve fonksiyonlarına sahip bir takım alt grupları bulunan heterojen bir hücre grubudur. İnsan mast hücreleri granüllerindeki triptaz ve kimaz içeriklerine göre iki ana gruba ayrımaktadı:

1. Triptaz ve kimaz içeren mast hücreleri: Başlıca deri ve ince barsak submukozasında bulunur.

2. Triptaz içeren mast hücreleri: Akciğer ve barsak mukozasında bulunan mast hücreleridir3,5.

Damarlar, sinirler ve deri ekleri çevresinde yoğun olarak yerleşen derideki mast hücreleri tüm deri hücrelerinin $\% 5$ 'inden daha azını oluşturmaktadır. Dermisten epidermise ve santralden perifere yaklaştıkça mast hücre sayısının arttığı gösterilmiştir8

\section{Mast hücre aktivasyonu ve medyatör salınımı}

Mast hücreleri allerjen, bakteri, parazit, travma, UV gibi değişik uyaranlar ve değişik yollarla aktive olup granüllerinden birçok medyatör salgılayarak fizyolojik ve patolojik süreçlere katılılar2,9. Uyarı sonrası oluşan ligandlar mast hücreleri üzerinde bulunan ve mikroçevreye bağlı olarak aktive olan spesifik reseptörleriyle eşleşirler (Tablo 1) ve böylelikle mast hücreleri aktivasyonu gerçekleşir3,10. Mast hücre aktivasyonu Fc reseptörleri ve Fc reseptörleri dışı olmak üzere başlıca iki temel mekanizmayla gerçekleşir. Ligand olarak IgE Fc epsilon Rl'e, Ig G ise Fc gama RIII'e bağlanarak Fc reseptör aracılı mast hücre aktivasyonuna yol açar. Bunların dışında SCF, kompleman, tümör nekrozis faktör (TNF), vazoaktif intestinal peptit, triptaz, katalisidin LL-37, alfa-melanosit sitümulan hormon gibi endojen peptitler ${ }^{2}$ ve yeni isimlendirmeyle Pattern recognition receptors (PRR) olarak bilinen Toll-like reseptörler (TLR) de Fc reseptörleri dışı yollarla mast hücrelerini aktive edebilir5,11-14. Mast hücre reseptörü ve ligandı birleşmesi sonucu aktive olan mast hücrelerinde farklı intraselüler sinyal aksları tetiklenerek mast hücre degranulasyonu gerçekleşir. Mast hücre degranulasyonu hızlı ve yoğun bir şekilde (anaflaktik tipte) ortaya çıkabileceği gibi bazı durumlarda yavaş ve kademeli bir salınım da olabilir2. Aktivasyon sonrasında hazırda var olan (depo) ve yeni üretilen olmak üzere iki temel grup medyatör salınımı gerçekleşir. Granüler medyatörler olarak da bilinen ve saniyeler- dakikalar içinde ortama salınan hazır medyatörlerin en önemlisi histamindir. Histamin ile birlikte bu grupta yer alan proteazlar, proteoglikanlar ve TNF-alfa vasküler geçirgenlik üzerine olan güçlü etkileriyle akut alerjik hastalıkların klinik bulgularının oluşumunda çok önemli bir rol oynamaktadır 5 . Yeni üretilen medyatörlerin bir grubu

Tablo 1. Belli başlı mast hücre ligandları ve reseptörleri

\begin{tabular}{|l|l|}
\hline Aktive Olan Reseptör & Ligand \\
\hline FcєRI & lgE \\
\hline FçRI & IgG \\
\hline C-Kit & SCF \\
\hline Adenozin reseptörleri & Adenozin \\
\hline TLR / 2,4,6,8 & Bakteri komponentleri \\
\hline PIR-A & ? \\
\hline C3aR, C5aR & C3a/C4a, C5a \\
\hline PAR (Proteazla aktive olan reseptör) & Trombin, Faktör Xa, Tripsin \\
\hline NK-1 (Nörokinin reseptörü 1) & Substance P \\
\hline
\end{tabular}

dakikalar içerisinde ortama salınan lökotrienler ve prostoglandinler gibi lipid medyatörleri içerirken diğer bir grubu ise saatler içerisinde salınımları gerçekleşen, IL'ler, microphage inflamatory protein (MIP)-I alfa, TNFalfa, SCF, granulocyte-macrophage colony-situmulating factor (GMCSF) gibi sitokin ve kemokinleri içerir. Sonuçta mast hücreleriden salınan bu depo ya da yeni üretilen medyatörler ile hücresel boyutta birçok farkl biyolojik etki ortaya çıkar10 (Tablo 2). En önemli ve en iyi bilinen mast hücre medyatörü olan histamin vasküler geçirgenliği artırırken düz kasların kasılmasına ve nörojenik vazodilatasyona yol açar. Bu etkilerin yanı sıra B hücre proliferasyonu ve langerhans hücre migrasyonu, doğa öldürücü hücreler, epitelyal hücreler ve T lenfositler üzerindeki etkileriyle doğal ve kazanılmış bağışıklık sistemi üzerinde de önemli etkilere sahiptir ${ }^{15}$. Son yıllarda histaminin tümör progresyonunda da rol oynadığı gösterilmiştir ${ }^{16}$. Mast hücre granüllerinin büyük bir bölümünü oluşturan ve nötral proteazlar olarak da bilinen triptaz ve kimaz; bir yandan fibroblast hiperplazisi ve aktivasyonuna yol açarlarken diğer yandan kollejenazı aktive ederek doku tamirinde rol oynarlar. Aynı zamanda nötral proteazlar nötrofil ve eozinofil göçünü uyarıp bazı proinflamatuar sitokinleri baskılarlar2,5. Bir diğer granüler medyatör grubundan olan proteoglikanlar (heparin ve kondroitin sülfat); güçlü antikoagülan etkilerinin yanı sıra anjiyogenezi uyarmak, komplemanı aktive, bazı kemokinleri ise inhibe etmek gibi başka önemli görevlere de sahiptirler 3 . Depo medyatörler içerisinde yer alan bir diğer grup ise sitokinlerdir. TNF, Vascular Endothelial Growth Factor (VEGF) gibi sitokinler efektör hücre göçüne neden olurken aynı zamanda anjiyogenezi de uyarırlar5 Mast hücre uyarısından dakikalar sonra yeni üretilerek ortama salınan prostoglandin ve lökotrienlerden oluşan lipid medyatörler ise; damar geçirgenliğini artırarak vasküler kaçağa ve düz kasları kasarak bronkospazma yol açarak alerjik semptomların oluşumunda önemli rol

\section{Tablo 2. Mast hücre medyatörleri ve temel biyolojik etkileri}

\begin{tabular}{|l|l|}
\hline Medyatör & Biyolojik Etki \\
\hline Histamin & Vazodilatasyon \\
\hline Heparin, Heparin sülfat & Anjiogenez, koagülasyon \\
\hline Kondrtoin sülfat & Dokunun yeniden şekillenmesi \\
\hline Triptaz & $\begin{array}{l}\text { Inflamasyon, ağrı, doku hasarı, PAR } \\
\text { aktivasyonu }\end{array}$ \\
\hline Kimaz & Inflamasyon, ağrı, doku hasarı \\
\hline Karboksipeptidaz & Enzim parçalanması \\
\hline Katepsinler & $\begin{array}{l}\text { Patojenlerin öldürülmesi, dokunun } \\
\text { yeniden şekillenmesi }\end{array}$ \\
\hline B-glukorinidaz & $\begin{array}{l}\text { Ekstraselüler matriksin yeniden } \\
\text { şekillenmesi }\end{array}$ \\
\hline NO sentaz & NO üretimi \\
\hline Endotelin & Sepsis \\
\hline Lökotrienler & $\begin{array}{l}\text { İflamasyon, lökosit göçü, endotel } \\
\text { adhezyonu, düz kas kontraksiyonu, } \\
\text { vasküler geçirgenlik }\end{array}$ \\
\hline Sitokinler & $\begin{array}{l}\text { Inflamasyon, lökosit çoğalması ve } \\
\text { aktivasyonu, immunregülasyon }\end{array}$ \\
\hline Büyüme faktörleri & Farklı Hc tipleri için büyüme faktörleri \\
\hline Antimikrobiyal ürünler & Patojenlerin öldürülmesi \\
\hline
\end{tabular}


üstlenirler. Diğer taraftan bu grupta yer alan platelet activating factor (PAF) ise nötrofil ve trombosit aktivasyonu, hipotansiyon ve damar geçirgenliği üzerinde etkilidir3,5. Çeşitli proinflamatuar sitokinler (TNF-alfa, IL-1, IL-6), Th2 ağıllıklı sitokinler (IL-4, IL-5, IL-10, IL-13), kemotaktik faktörler (IL-8, MIP-1alfa gibi) ve büyüme faktörleri ise saatler içerisinde yeni üretilerek inflamatuar ve immun yanıtlar üzerinde etki göstererirler3,5,6. Sonuç olarak mast hücreleri aktivasyon sonrası salgılanan medyatörleri aracılığı ile çeşitli fizyolojik, uygunsuz ve kronik aktivasyon durumunda ise patolojik süreçlere katılan önemli hücrelerdir.

\section{Alerjik inflamasyonda mast hücrelerin rolü}

Tip 1 aşırı duyarlılık (ani hipersensitivite) yanıtları IgE bağımlı mast hücre aktivasyonu sonucu oluşur. Ayrıca mast hücre kökenli IL-8 ve TNFalfa'nın Tip 4 aşıı duyarlık (gecikmiş tip hipersensitivite) reaksiyonlarının gelişiminde önemli rol oynadığı bilinmektedir ${ }^{3}$. Matsuda ve arkadaşları yaptıkları deneysel bir çalışmada; genetik olarak mast hücreleri eksik farelerde kene enfestasyonuna karşı direnç gelişiminde hata oluşurken doğru yanıtın ancak mast hücre ve IgE'nin beraber varlığında mümkün olduğunu göstermişler ve sonuçta tip 1 aşırı duyarlıık yanıtlarının organizma için fizyolojik bir rolü de olduğu sonucuna varmışlardır ${ }^{17}$.

\section{Alerjik inflamasyon dışındaki inflamasyonda mast hücrelerinin rolü}

Mast hücreleri uyaranın tipi ve özelliğine bağlı olarak çeşitli biyolojik aktif ürünler üreterek, tetikleme ya da baskılama yoluyla, bağışıklık yanıtlarının üzerinde önemli etkilere sahiptir ${ }^{10}$.

Bu hücreler doğal bağışıklıkta bakteri, virüs ve parazitlere karşı geliştirilen konak savunmasında önemli rol oynar ${ }^{14}$. TNF-alfa üretimleri ve buna bağlı gelişen nötrofil göçü mast hücrelerinin bakteriyel enfeksiyonlara karşı korunmada en önemli silahı olarak kabul edilmektedir ${ }^{18}$. Bunun dışında bazı bakterileri direkt olarak fagosite ederek ve katelisidin gibi antimikrobiyal peptitlerin üretimine yol açarak bakteriyel enfeksiyonlara karşı koruyucu etki gösterebilirler ${ }^{19}$, 20. Enfeksiyöz ajanlarla temas sonrası mast hücre aktivasyonu TLR aracılığıyla oluşur. Mast hücreleri üzerindeki TLR1,2,5,9 Gram (+) bakteriler ve mikoplazma, TLR3,7,8 virüsler, TLR4 ise Gram (-) bakteriler için fizyolojik ligand görevi görmektedir21. Bir çalışmada atopik dermatitte ekzemanın Staphylococcus aureus ile şiddetlenmesi mast hücrelerinin TLR ile aktivasyonuna bağlanmıştır22. Mast hücrelerinin en önemli fizyolojik fonksiyonlarından biri de lgE antikorları aracılığı ile paraziter enfestasyonlara karşı savunmada aldıkları roldür14. Mast hücreleri kazanılmış bağışıklık yanıtların oluşturulmasında da önemlidir. Üzerlerinde MHC class I ve II sunumu gerçekleşen bu hücreler, T hücreleri için antijen sunan hücreler arasında sayılmaktadır². Mast hücre kaynaklı TNF-alfa Langerhans hücrelerinin ve dolaşımdaki T lenfositlerin bölgesel lenf nodlarına göçüne yol açar ve özellikle bakteriyel enfeksiyonlar sırasındaki lenf nodu hipertrofisinde rol oynar2,6. Mast hücreleri ayrıca ürettikleri çeşitli sitokinler ile B hücre gelişimi ve fonksiyonları üzerinde de etki gösterirler. B hücreleri ile ilişkileri sonucu, özellikle IL-4 varlığında; IgE üretimini indüklerler ${ }^{10}$. Mast hücreleri aynı zamanda antiinflamatuar ve immunsupresif etkileri olan hücrelerdir. Salgıladıkları bazı medyatörlerin (IL-4, IL-10, TGF- $\beta$, histamin gibi) direk antiinflamatuar etkiye sahip olduğu bilinmektedir. Mast hücre proteazlarından kimaz; IL-5, IL- 6, IL-13 ve TNF-alfa gibi bazı proinflamatuar medyatörleri degrede ederek inflamatuar yanıtları baskılar ${ }^{2}$. Mast hücrelerinin bir diğer önemli görevleri de Treg hücreleri üzerindeki etkileri ile deri greftlerine karşı immun tolerans gelişiminde oynadıkları roldür2,6,23.

\section{Mast hücrelerinin yara iyi leşmesi, anjiyogenez ve tümör gelişimi üzerindeki etkileri}

Mast hücrelerinin yara iyileşmesinin, başlangıç dönemindeki inflamatuar yanıttan başlayarak dokunun yeniden şekillenmesi ve reepitelizasyon sürecine dek, tüm fazlarında etkili olduğu düşünülmektedir6. Mast hücrelerinin fibroblast proliferasyonu ve kollajen sentezini uyardığı; bu şekilde hem yara iyileşmesi hem de skar oluşumunda önemli rol oynadığı bilinmektedir ${ }^{14}$. Bazı mast hücre medyatörleri ise anjiyogenezi uyarır böylece fizyolojik koşullarda yara iyileşmesi, patolojik koşullarda ise tümör gelişimi üzerinde etki gösterirler6. Mast hücrelerinin tümör gelişimindeki en önemli rolleri anjiyogenezi uyarmalarıdır ancak tümörogenezde bunun dışında da önemli rollere sahiptirler. Örneğin mast hücre medyatörlerinden triptaz ve histaminin tümör progresyonuna yol açtığı, histamin dahil olmak üzere birçok medyatörün immun yanıtlar üzerindeki etkileri yoluyla tümör gelişimine katkıda bulunduğu kabul edilmektedir. Buna karşıllı TNF-alfa, IL-1, IL-6 gibi diğer mast hücre medyatörlerinin ise anjiyogenez ve tümör gelişimi üzerinde inhibitör etkilerinin olduğu gösterilmiştir. Günümüz itibari ile çeşitli mast hücre medyatörlerinin konsantrasyonlarına, kofaktörlerlere ve tümör içinde ya da çevresinde yerleşim özelliklerine göre pro ya da antikanser etki gösterebilecekleri düşünülmektedir24.

Sonuç olarak günümüzdeki bilgiler ışığında; mast hücreleri hem proinflamatuar hem de immunsupresif fonksiyonlar göstererek bağışıklık sisteminin fizyolojik ve patolojik yanıtlarında önemli rol oynayan hücreler olarak kabul edilmektedirler.

\section{Kaynaklar}

1. Amin K. The role of mast cells in allergic inflammation. Respiratory medicine. 2012;106:9-14.

2. Harvima IT, Nilsson G. Mast cells as regulators of skin inflammation and immunity. Acta Dermato-venereologica 2011;91:644-50.

3. Maurice W. van der Heijden, Hanneke P.M. van der Kleij, Martin Röcken, Redegeld. FA: Mast cells.Skin immune system (SIS) : cutaneous immunology and clinical immunodermatology. In: Bos JD, editor. 3rd ed. Boca Raton, CRC Press 2005;237-63.

4. Anand $P$, Singh $B$, Jaggi AS, Singh N. Mast cells: an expanding pathophysiological role from allergy to other disorders. Naunyn-Schmiedeberg's Archives of Pharmacology. 2012;385:657-70.

5. Marshall JS. Mast-cell responses to pathogens. Nature reviews Immunology 2004;4:787-99.

6. Gilfillan AM, Beaven MA. Regulation of mast cell responses in health and disease. Critical Reviews in Immunology 2011;31:475-529.

7. Droogendijk HJ, Kluin-Nelemans HJ, van Doormaal JJ, Oranje AP, van de Loosdrecht AA, van Daele PL. Imatinib mesylate in the treatment of systemic mastocytosis: a phase II trial. Cancer 2006;107:345-51.

8. Weber A, Knop J, Maurer M. Pattern analysis of human cutaneous mast cell populations by total body surface mapping. The British journal of Dermatology 2003;148:224-8.

9. Maurer M, Theoharides T, Granstein RD, Bischoff SC, Bienenstock J, Henz $B$, et al. What is the physiological function of mast cells? Experimental Dermatology 2003;12:886-910.

10. Gri G, Frossi B, D'Inca F, Danelli L, Betto E, Mion F, et al. Mast cell: an emerging partner in immune interaction. Frontiers in Immunology 2012;3:120.

11. Leal-Berumen I, Conlon P, Marshall JS. IL-6 production by rat peritoneal mast cells is not necessarily preceded by histamine release and can be induced by bacterial lipopolysaccharide. J Immunol 1994;152:5468-76.

12. Supajatura V, Ushio H, Nakao A, Okumura K, Ra C, Ogawa H. Protective roles of mast cells against enterobacterial infection are mediated by Toll-like receptor 4. J Immunol 2001;167:2250-6.

13. King CA, Anderson R, Marshall JS. Dengue virus selectively induces human mast cell chemokine production. Journal of Virology 2002;76:8408-19. 
14. Gurish MF, M.C. C. Mast cells: Development, identification, and physiologic roles. Uptodate [Internet]. 2013.

15. Ferstl R, Akdis CA, O'Mahony L. Histamine regulation of innate and adaptive immunity. Frontiers in bioscience : a journal and virtual library 2012;17:40-53

16. Medina VA, Rivera ES. Histamine receptors and cancer pharmacology. British journal of pharmacology 2010;161:755-67.

17. Matsuda $H$, Fukui $K$, Kiso $Y$, Kitamura $Y$. Inability of genetically mast cell-deficient W/Wv mice to acquire resistance against larval Haemaphysalis longicornis ticks. The Journal of parasitology 1985;71:443-8.

18. Malaviya R, Ikeda T, Ross E, Abraham SN. Mast cell modulation of neutrophil influx and bacterial clearance at sites of infection through TNF-alpha. Nature 1996;381:77-80.

19. Di Nardo A, Vitiello A, Gallo RL. Cutting edge: mast cell antimicrobial activity is mediated by expression of cathelicidin antimicrobial peptide. J Immunol 2003; 170:2274-8.
20. Malaviya R, Ross EA, MacGregor JI, Ikeda T, Little JR, Jakschik BA, et al. Mast cell phagocytosis of FimH-expressing enterobacteria. J Immunol 1994:152:1907-14

21. Sandig H, Jobbings CE, Roldan NG, Whittingham-Dowd JK, Orinska Z, Takeuchi $\mathrm{O}$, et al. IL-33 causes selective mast cell tolerance to bacterial cell wall products by inducing IRAK1 degradation. European journal of immunology 2013;43:979-88.

22. Rocha-de-Souza CM, Berent-Maoz B, Mankuta D, Moses AE, Levi-Schaffer F. Human mast cell activation by Staphylococcus aureus: interleukin-8 and tumor necrosis factor alpha release and the role of Toll-like receptor 2 and CD48 molecules. Infection and immunity 2008;76:4489-97.

23. Lu LF, Lind EF, Gondek DC, et al. Mast cells are essential intermediaries in regulatory T-cell tolerance. Nature 2006;442:997-1002.

24. Dyduch G, Kaczmarczyk K, Okon K. Mast cells and cancer: enemies or allies? Polish journal of pathology : official journal of the Polish Society of Pathologists 2012;63:1-7 